\title{
Incidence and prevalence of juvenile chronic arthritis: a population survey
}

\author{
B ANDERSSON GÄRE, ${ }^{12}$ A FASTH, ${ }^{1}$ J ANDERSSON ${ }^{3}$ G BERGLUND, \\ H EKSTRÖM, ${ }^{4}$ M ERIKSSON,${ }^{5}$ L HAMMARÉN, ${ }^{6}$ L HOLMQUIST, \\ E RONGE, ${ }^{8}$ AND A THILEN ${ }^{2}$
}

From the Departments of Pediatrics, ${ }^{1}$ University of Göteborg, ${ }^{2}$ Central Hospitals of Jönköping, ${ }^{3}$ Vänersborg, ${ }^{4}$ Karlstad, ${ }^{5}$ Uddevalla, ${ }^{6}$ Borås, ${ }^{7}$ Mölndal, and ${ }^{8}$ Skövde

SUMMARY In a population based epidemiological survey of juvenile chronic arthritis (JCA), performed in Western Sweden in 1983, an incidence of 12/100 000 was found. The estimated prevalence was 56/100 000. Subgroup distribution showed a preponderance of mono- and pauciarticular forms. The peak age of onset was between 0 and 4 years of age. Girls predominated over boys in a ratio of 3:2. Overall, $30 \%$ were antinuclear antibody (ANA) positive, $9 \%$ rheumatoid factor (RF) positive, and eye involvement occurred in $10 \%$ of the children. The results suggest differences in population based studies of JCA compared with previously reported hospital based series.

Key words: epidemiology, age distribution, sex distribution, ANA, RF, iritis.

Chronic arthritis in children was first described by George F Still almost 100 years ago. ${ }^{1}$ Interestingly, he already at that time speculated about several types of chronic arthritis in childhood. Through the years this heterogeneity has become obvious, with different patterns of clinical presentation, immunological characteristics, and long term prognosis.

Epidemiologic data are conflicting because of the heterogeneity of the disease and the lack of standardised criteria for diagnosing juvenile chronic arthritis and for dividing the children into subgroups. In addition, most incidence and prevalence figures are based on patients cared for at rheumatology clinics and not on population surveys.

In the present study a defined population was investigated in an attempt to find frequency figures for juvenile chronic arthritis, both for the hospital cases and for the milder cases seen only by the local paediatrician.

\section{Patients and methods}

PAT I E N T S

The population base consisted of 400600 children,

Accepted for publication 15 October 1986

Correspondence to Dr B Andersson Gäre, Department of Pediatrics II, Barnkliniken, Östra sjukhuset, S-416 85 Göteborg, Sweden.
0-16 years of age, in five counties in south western Sweden. Each department of paediatrics (altogether eight) collected data from patients visiting their paediatric rheumatology clinic and from those seen by local paediatricians in collaboration with the regional representative.

\section{CRITERIA FOR INCLUSION}

The European League Against Rheumatism (EULAR) criteria for juvenile chronic arthritis (JCA) were used to define chronic arthritis and to divide patients into subgroups. ${ }^{2}$ According to these criteria patients with onset of their arthritis before the 16th birthday and with a minimum duration of the disease of three months were included, and cases of infectious arthritis and connective tissue diseases were excluded.

Within the JCA group the following subgroups were distinguished: (a) onset with systemic features; $(b)$ onset with polyarthritis in the absence of marked systemic features, five or more joints affected; (c) onset with arthritis affecting four or less jointspauciarticular, or in the case of only one jointmonoarticular.

Within these groups it was possible to identify children with juvenile ankylosing spondylitis (JAS), psoriatic arthropathy (JPA), and arthropathies associated with inflammatory bowel disease (IBD). 
According to EULAR they were included but listed separately. Clinical findings were evaluated centrally by one of the authors (BAG), who classified the patients into subgroups according to the EULAR criteria.

\section{LA B ORATORY TESTS}

All patients were tested for rheumatoid factor (RF) (latex agglutination test) and antinuclear antibodies (ANA) (indirect immunofluorescence) using rat kidney sections. Titres of $1 / 20$ and $1 / 25$ were considered positive for RF and ANA respectively.

\section{CALCULATIONS OF INCIDENCE AND}

\section{PRE V A L E N C E}

The incidence of JCA was calculated from data prospectively collected from 1 January to 30 September 1983.

Prevalence was based on data from the same period as for incidence figures, as well as retrospectively collected data for patients with JCA covering the three year period 1 October 1980 to 30 September 1983. Children not receiving medication and free from symptoms and signs for more than three years were excluded. Demographic statistics were obtained from the Statistical Abstract of Sweden 1983. ${ }^{3}$

\section{Results}

I NCI DENCE

During the nine months' observation period 36 cases of JCA were diagnosed. With a population of 400600 children, $0-16$ years of age, in the region surveyed the calculated incidence is $12 / 100000$ children a year. The distribution among JCA subgroups was: monoarticular 11 ; pauciarticular $10 . \overline{-}$. polyarticular 10; systemic 4, and JAS 1 .

\section{PREV A L E N C E}

Two hundred and twenty three cases of JCA wereo identified, giving a prevalence of 56/100 000 chil $\frac{\bar{s}}{\sqrt{2}}$ dren. The distribution into subgroups at the time of onset and at 1 October 1983 is shown in Table 1.0

Of the 18 patients that up to 1 October 1983 changed their subgroup from mono- to pauciarticu? lar or from pauci- to polyarticular disease, 13 were girls. In the group with systemic disease at onset $4 / 1$. were later classified as polyarticular JCA. At the onset no patient was diagnosed as having arthritis associated with IBD, but two patients later de veloped ulcerative colitis (one poly- and one

Table 1 Distribution into subgroups of JCA according to EULAR criteria ${ }^{2}$

\begin{tabular}{|c|c|c|c|c|}
\hline \multirow[t]{2}{*}{ Subgroup } & \multicolumn{2}{|c|}{ Onset type* } & \multicolumn{2}{|c|}{ Present type } \\
\hline & $n$ & $\%$ & $n$ & $\%$ \\
\hline Monoarticular & 55 & 24 & 37 & 17 \\
\hline Pauciarticular & 91 & 41 & 85 & 38 \\
\hline Polyarticular & 55 & 25 & 78 & 35 \\
\hline Systemic & 15 & 7 & 11 & 5 \\
\hline JAS & 2 & 1 & 4 & 2 \\
\hline IBD & 0 & 0 & 3 & 1 \\
\hline JPA & 5 & 2 & 5 & 2 \\
\hline Total & 223 & 100 & 223 & 100 \\
\hline
\end{tabular}

*Onset type: patients grouped according to manifestations during first six months of the disease (EULAR criteria ${ }^{2}$ ).

+Present type: patients grouped according to disease status at the end of the study 1 October 1983 .

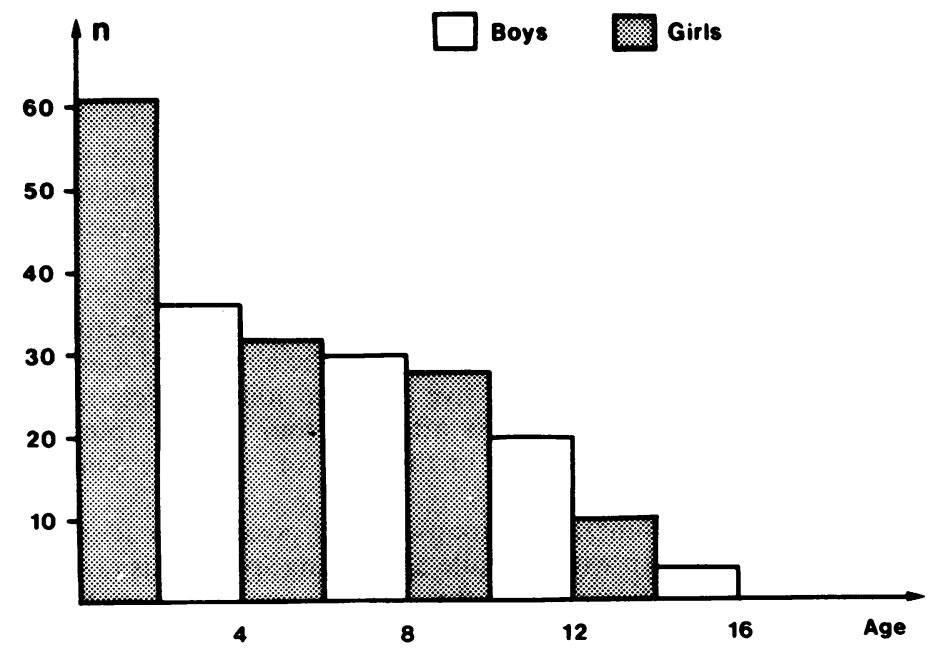

Fig. 1 Prevalence of JCA. Age and sex distribution at onset. 
pauciarticular JCA), and one child with pauciarticular onset later had Crohn's disease diagnosed.

AGE AND SEX DISTRIBUTION (Figs 1 and 2) The peak age of onset was between 0 and 4 years. A second peak around puberty was not found. For the group with polyarticular JCA no peak incidence age was found, rather the onset ages were evenly distributed throughout childhood.

Girls predominated over boys in the ratio of $3: 2$ for the whole group. In the age group 0-4 years at onset there was a female preponderance of $61: 36$. Among the children with mono- and pauciarticular JCA a sex ratio of 89:57 was found (girls/boys). In the group with systemic disease there were 14 boys and one girl. All the patients with JAS were boys.

\section{SEROLOG Y}

Twenty ( $9 \%$ ) children were RF positive. They were evenly distributed among all ages and subgroups. In the polyarthritic group seven $(13 \%)$ children were RF positive.

Altogether, 67 (30\%) were ANA positive: $40 \%$ in the monoarticular, $36 \%$ in the pauciarticular, $23 \%$ in the polyarticular, and $18 \%$ in the systemic disease group.

\section{CHRONIC IRITIS}

Chronic iritis occurred in $22(10 \%)$ children (Table 2 ). They belonged mainly to the mono- and pauciarticular JCA subgroups. An increased frequency $(33 \%)$ of eye disease was found among ANA positive patients as compared with ANA negative patients $(4 \% ; \mathrm{p}<0.001)$ (fourfold tables).
Table 2 Iritis and ANA positivity in JCA subgroups

\begin{tabular}{lrrrl}
\hline Subgroup* & $n$ & ANA (+) & Iritis (+) $\begin{array}{l}\text { Iritis (+) } \\
\text { and } A N A \\
(+)\end{array}$ \\
\hline Monoarticular & 37 & 15 & 5 & 4 \\
Pauciarticular & 85 & 31 & 12 & 8 \\
Polyarticular & 78 & 16 & 4 & 4 \\
Systemic & 11 & 2 & 0 & 0 \\
JAS & 4 & 1 & 1 & 0 \\
IBD & 3 & 1 & 0 & 0 \\
JPA & 5 & 1 & 0 & 0 \\
Total & 223 & 67 & 22 & 16 \\
\hline
\end{tabular}

'Patients grouped according to 'present type'. See Table 1.

\section{Discussion}

The need for population based surveys, rather than hospital based studies, in order to define epidemiological parameters of JCA, has been pointed out by several authors. ${ }^{45}$ Such studies are not found in the literature, however. The present survey is population based, which could explain many of the differences compared with previous studies.

Epidemiological figures of JCA are conflicting not only because of the selectivity of the material studied but also because of lack of or differences in diagnostic criteria. During the last decade several sets of diagnostic criteria have been proposed (Table 3). The main differences are found in the duration of the observation period before diagnosis and in the list of exclusion criteria. The observation
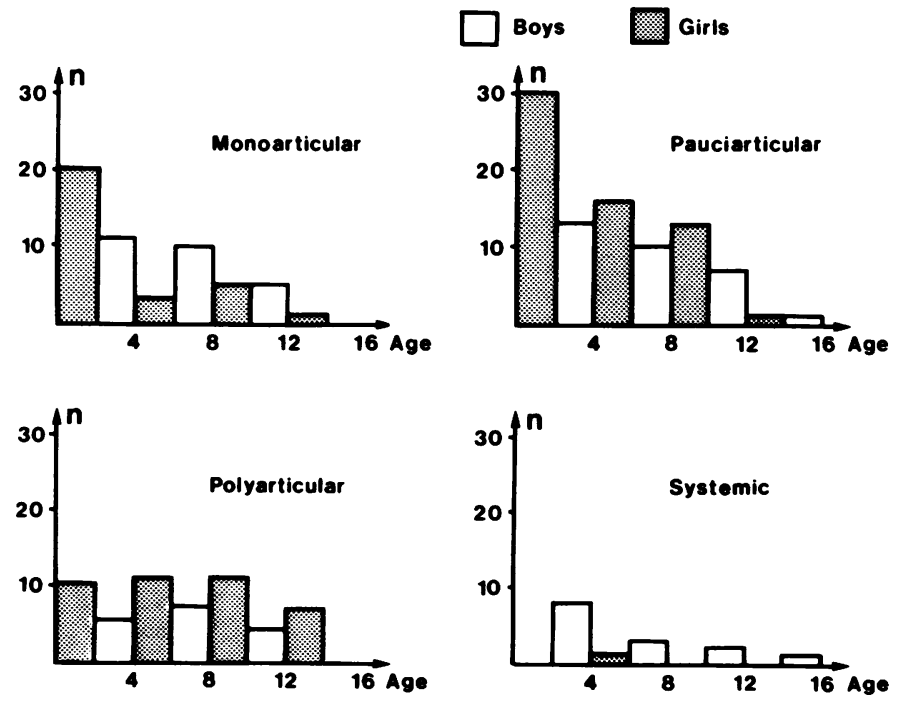

Fig. 2 Prevalence of JCA. Age and sex distribution at onset in various subgroups according to EULAR criteria. 
period of six weeks proposed in the North American criteria $^{7}$ seems too short since some patients with viral and reactive arthritis have not recovered during that period, leading to an overestimation of the frequency. An observation period of three months before diagnosis as proposed by others would avoid the problem of including reactive arthritis. ${ }^{268} \mathrm{JAS}$, JPA, and IBD associated arthritis are not included in the North American criteria but are included in the EULAR criteria. Since some patients initially classified as mono- or pauciarticular JCA will during the course of time change to JAS, JPA, or IBD, the broader criteria of EULAR are preferable.

The high incidence of $12 / 100000$ children a year found in our study supports our hypothesis that a prospective population based survey reveals cases missed in hospital based series. Our survey period of nine months is short, and it is possible that a more extended study period would have resulted in an even higher incidence. Previously published incidence figures summarised in Table 4 show a range from 2.6 to 9.2 per 100000 , but these are based on hospital material collected retrospectively. The figure closest to ours reported by Sullivan et $a l^{11}$ is, however, not comparable as it is hospital based, retrospectively collected, and uses the North Amer- ican short observation period before diagnosis음 Since the prevalence in our study, $56 / 100000$. children, is based partly on retrospectively collected cases, this number is probably an underestimationo owing to the loss of mild cases. Prevalence figures for JCA show a very wide range of 8-220/100 006 children (Table 5). The highest prevalence, reportedp by the National Health Interview Survey in the USA, ${ }^{15}$ probably again reflects the effect of thes shorter observation period before diagnosis in North $\vec{P}$ America and the low specificity of the method used $\overrightarrow{\overrightarrow{.}}$ diagnosing arthritis by population questionnaires $\omega_{\sigma}^{\omega}$ Another important factor not discussed in previous reports is assessment of remission. In our survey children not receiving medication and free fromp symptoms and signs for three years or more were excluded. After our study was completed EULAR proposed a two year period, rather than three yearso as a definition of remission (EULAR standing committee, Moscow, 1983).

A bimodal distribution for the age at onset of JCA has been suggested with one peak in the age group below 5 years and another in the 10-16 ag£ group. ${ }^{10}{ }^{17}$ In contrast, we found a single peak in the age group $0-4$ years, which was most prominent fog the mono- and pauciarticular subgroups. Age a

Table 3 Differences between commonly used criteria for chronic arthritis in children. (With permission from Kvien et $a l^{8}$ )

\begin{tabular}{|c|c|c|c|c|}
\hline & $\begin{array}{l}\text { English } \\
\text { (ref. 6) }\end{array}$ & $\begin{array}{l}\text { North } \\
\text { American } \\
\text { (ref. 7) }\end{array}$ & $\begin{array}{l}\text { EULAR/WHO } \\
\text { (ref. 2) }\end{array}$ & $\begin{array}{l}\text { Oslo } \\
\text { (ref. 8) }\end{array}$ \\
\hline Age of patients (years) & $0-16$ & $0-16$ & $0-16$ & $0-16$ \\
\hline Duration of observation period & 3 months & 6 weeks & 3 months & 3 months \\
\hline Biopsy in monoarticular disease & + & - & - & $\begin{array}{l}+(\text { except if } \\
\text { iridocyclitis })\end{array}$ \\
\hline Onset subtypes & - & + & + & + \\
\hline Definition of disease manifestations & - & - & - & + \\
\hline List of exclusion & - & + & + & + \\
\hline Terminology & $\mathrm{JCP}$ & JRA & JCA & JRA \\
\hline
\end{tabular}

Table 4 Incidence of chronic arthritis in children, from national surveys

\begin{tabular}{|c|c|c|c|c|}
\hline Reference & $\begin{array}{l}\text { Geographic } \\
\text { location }\end{array}$ & Type of survey & Criteria & $\begin{array}{l}\text { Incidence } \\
\text { (No of cases/ } \\
100 \text { 000) }\end{array}$ \\
\hline Sury ${ }^{9}$ & Denmark & $\begin{array}{l}\text { Rheumatology clinic and } \\
\text { estimation }\end{array}$ & $\begin{array}{l}\text { North } \\
\text { American } 1949\end{array}$ & $2 \cdot 7$ \\
\hline Laaksonen $^{10}$ & Finland & Rheumatology clinic & English & $3 \cdot 8$ \\
\hline Sullivan et $a^{11}$ & Michigan & Rheumatology clinic & North American & $9 \cdot 2$ \\
\hline Hill $^{12}$ & British Colombia & Paediatric clinic & $?$ & $\begin{array}{l}2 \cdot 6 \text { (overall) } \\
7 \cdot 2 \text { (Indian) }\end{array}$ \\
\hline Present study & South western Sweden & Total population based & EULAR (WHO) & 12 \\
\hline
\end{tabular}


Table 5 Prevalence of chronic arthritis in children, from national surveys

\begin{tabular}{|c|c|c|c|c|}
\hline Reference & $\begin{array}{l}\text { Geographic } \\
\text { location }\end{array}$ & Type of survey & Criteria & $\begin{array}{l}\text { Prevalence } \\
\text { (No of cases/ } \\
100 \text { 000) }\end{array}$ \\
\hline Bille $^{13}$ & Sweden & Rheumatology clinic & $?$ & 8 \\
\hline Bywaters $^{14}$ & South east England & $\begin{array}{l}\text { Rheumatology clinic/ } \\
\text { population }\end{array}$ & English & 60 \\
\hline NHIS $^{15}$ & USA & Population questionnaire & North American & 220 \\
\hline Baum $^{4}$ & New York state & $\begin{array}{l}\text { Practitioner } \\
\text { questionnaire }\end{array}$ & North American & 110 \\
\hline Gewanter et $a l^{16}$ & USA New York state & Pooled practitioner surveys & North American & $50(20-100)$ \\
\hline Present study & South western Sweden & Population based & EULAR (WHO) & 56 \\
\hline
\end{tabular}

onset was evenly distributed in the polyarthritic subgroup. Mono- and pauciarticular cases predominated, comprising $65 \%$ of all patients. Such a predominance is not found in other series and could reflect a selection of more severe polyarthritic cases in the hospital based series. ${ }^{10}{ }_{17-19}$

ANA positivity was found in $30 \%$ of the whole series, with the highest frequency $(50 \%)$ in the mono- and pauciarticular subgroups. Similar rates were found in previous investigations, ${ }^{17-21}$ though ANA positivity as high as $60 \%$ has recently been reported using a more sensitive method. ${ }^{22}$ Schaller et al have an increased risk for iridocyclitis in ANA positive children compared with ANA negative patients. ${ }^{23}$ This correlation was confirmed in the present study. The frequency of RF positivity (9\%) is in agreement with earlier reports. ${ }^{17-21}$

The differences found compared with results of previous work encourage further epidemiological studies using prospectively collected population based materials followed up over an extended time period, in order to increase our knowledge of disease incidence and prevalence, the natural history of various subgroups, and the factors predicting long term prognosis.

This study was supported by grants from the Swedish National Association against Rheumatism and the Gothenburg Association against Arthritis. The secretarial assistance of Ms Ingegerd Jonasson and Ms Inga Jonsson is gratefully acknowledged.

\section{References}

1 Still G F. On a form of chronic joint disease in children. Med Chir Trans 1897; 80: 47-59.

2 Wood P H. Nomenclature and classification of arthritis in children. In: Munthe $\mathrm{E}$, ed. The care of rheumatic children. Basel: EULAR, 1978: 47.

3 Statistical abstract of Sweden 1982/1983. Stockholm: Statistics Sweden, 1983.
4 Baum J. Epidemiology of juvenile rheumatoid arthritis (JRA). Arthritis Rheum 1977; 20 (suppl): 158-9, 164.

5 Hochberg M C. Adult and juvenile rheumatoid arthritis: current epidemiologic concepts. Epidemiol Rev 1981; 3: 27-41.

6 Ansell B M, Bywaters E G L. Copeman's textbook of the rheumatic diseases. Edingburgh, London, New York: Churchill Livingstone, 1978.

7 Brewer E J, Bass J, Baum J, et al. Current proposed revision of JRA criteria. Arthritis Rheum 1977; 20 (suppl): 195.

8 Kvien T K. Høyeraal H M. Kăss E. Diagnostic criteria of rheumatoid arthritis in children. Scand J Rheumatol 1982; 11: 187-92.

9 Sury B. Rheumatoid arthritis in children. A clinical study. Copenhagen: Munksgaard, 1952. (Thesis.)

10 Laaksonen A L. A prognostic study of juvenile rheumatoid arthritis. Acta Paediatr Scand 1966: 166 (suppl).

11 Sullivan D B, Cassidy J T, Petty R E. Pathogenic implications of age of onset in juvenile rheumatoid arthritis. Arthritis Rheum 1975; 18: 251-55.

12 Hill R. Juvenile arthritis in various racial groups in British Colombia. Arthritis Rheum 1977; 20 (suppl): 162.

13 Bille B S V. Chronic polyarthritis in children and its gold therapy. Nord Med 1948: 37: 307-10.

14 Bywaters E G L. Diagnostic criteria for Still's disease. In: Bennett $\mathrm{P} \mathrm{H}$, Wood $\mathrm{P} \mathrm{H}$, eds. Population studies of the rheumatic diseases. New York: Exerpta Medica, 1968.

15 Bonham G S. Prevalence of chronic skin and musculoskeletal conditions. United States 1976. National Health Interview Survey, Series 10. Udshew, 1978.

16 Gewanter H L, Roghmann K J, Baum J. The prevalence of juvenile arthritis. Arthritis Rheum 1983; 26: 599-603.

17 Ansell B M, Bywaters E G L. Rheumatoid arthritis (Still's disease). Pediatr Clin North Am 1963; 10: 921-39.

18 Schaller J. Chronic arthritis in children. Clin Orthop 1984; 182: 79-89.

19 Stoeber E. Prognosis in juvenile chronic arthritis. Eur J Pediatr 1981; 135: 225-8.

20 Miller J J. Juvenile rheumatoid arthritis. Littleton: PSG Publishing Co, 1979.

21 Ansell B. Juvenile chronic arthritis-series 3. Arthritis Rheum 1977; 20 (suppl): 176-8.

22 Osborn T G. Use of the Hep-2 cell substrate in the detection of antinuclear antibodies in juvenile rheumatoid arthritis. Arthritis Rheum 1984; 27: 1286-9.

23 Schaller J G, Johnson G D, Holborow E J, Ansell B M, Smiley W K. Antinuclear antibodies (ANA) in patients with iridocyclitis and juvenile rheumatoid arthritis (Still's disease). Arthritis Rheum 1974; 17: 409-16. 